\title{
Collective Critical Care Ambulance: an innovative transportation of critical care patients by bus in COVID-19 pandemic response
}

Thierry Lentz, Charles Groizard, Abel Colomes, Anna Ozguler, Michel Baer and Thomas Loeb

\begin{abstract}
Background: During the COVID-19 pandemic, as the number of available Intensive Care beds in France did not meet the needs, it appeared necessary to transfer a large number of patients from the most affected areas to the less ones. Mass transportation resources were deemed necessary. To achieve that goal, the concept of a Collective Critical Care Ambulance (CCCA) was proposed in the form of a long-distance bus re-designed and equipped to accommodate up to six intensive care patients and allow Advanced Life Support (ALS) techniques to be performed while en route.
\end{abstract}

Methods: The expected benefit of the CCCA, when compared to ALS ambulances accommodating a single patient, was to reduce the resources requirements, in particular by a lower personnel headcount for several patients being transferred to the same destination. A foreseen prospect, comparing to other collective transportation vectors such as airplanes, was the door-to-door capability, minimalizing patients' handovers for safety concerns and time efficiency. With the project of a short-distance transfer of several Intensive Care Unit (ICU) patients together, the opportunity came to test the CCCA under real-life conditions and evaluate safely its technical feasibility and impact in time and resources saving, before it could be proposed for longer distances.

Results: Four COVID-19 patients were transported over $37 \mathrm{~km}$. All patients were intubated and under controlled ventilation. One of them was under Norepinephrine support. Mean loading time was 1 min $39 \mathrm{~s}$. Transportation time was $29 \mathrm{~min}$. At destination, the mean unloading time was $1 \mathrm{~min} 15 \mathrm{~s}$. No serious adverse effect, in particular regarding hemodynamic instability or ventilation disorder, has been observed. No harmful incident has occurred.

Conclusions: It was a very instructive test. Collective medical evacuation by bus for critically ill patients under controlled ventilation is suitable and easy to implement. Design, ALS equipment, power autonomy, safety and resources saving, open the way for carrying up to 6 ICU-patients over a long distance. The CCCA could bring a real added-value in an epidemic context and could also be helpful in many other events generating multiple victims such as an armed conflict, a terrorist attack or a natural disaster.

Keywords: Emergency medical service, Critical care transport, Interhospital transfer of critically ill patients, Collective transport, Mass casualty incidents, Disaster

\footnotetext{
* Correspondence: anna.ozguler@aphp.fr

SAMU des Hauts-de-Seine, Assistance Publique - Hôpitaux de Paris,

Université Paris-Saclay, Hôpital Raymond Poincaré, 104, boulevard Raymond

Poincaré, 92380 Garches, France
}

(c) The Author(s). 2021 Open Access This article is licensed under a Creative Commons Attribution 4.0 International License, which permits use, sharing, adaptation, distribution and reproduction in any medium or format, as long as you give appropriate credit to the original author(s) and the source, provide a link to the Creative Commons licence, and indicate if changes were made. The images or other third party material in this article are included in the article's Creative Commons licence, unless indicated otherwise in a credit line to the material. If material is not included in the article's Creative Commons licence and your intended use is not permitted by statutory regulation or exceeds the permitted use, you will need to obtain permission directly from the copyright holder. To view a copy of this licence, visit http://creativecommons.org/licenses/by/4.0/ The Creative Commons Public Domain Dedication waiver (http://creativecommons.org/publicdomain/zero/1.0/) applies to the data made available in this article, unless otherwise stated in a credit line to the data. 


\section{Background}

When the COVID-19 pandemic hit France in January 2020 , it appeared quickly that the number of available Intensive Care Unit (ICU) beds would not meet the needs, notably in the Grand Est and the Île-de-France regions. Consequently, the Ministry of Health made the decision to transfer patients from saturated ICUs to less crowded ones by interhospital transfers to less affected regions. Numerous individual transfers were made by air, ground or sea transportation and collective transport innovative features appeared, such as 10 "hospital trains", following a previously validated concept [1].

In this context, a long-distance bus turned into a Collective Critical Care Ambulance (CCCA) was considered for testing under real conditions.

The main objective of this trial was to validate a proof of concept for operating a long-distance bus as a CCCA, transporting critically ill patients requiring Advanced Life Support (ALS) techniques to be performed while en route, with a door-to-door capability reducing handover manoeuvres. The secondary objective was to validate the specifications of this CCCA.

\section{Methods}

In an Emergency Medical Service (named SAMU) located in Hauts-de-Seine province, a working group dedicated to Exceptional Healthcare Situations (EHS Group) proceeded with the re-design of the interior space of a Man ${ }^{\text {nt }}$ Lion's Coach model, one of the largest buses currently in use.

\section{Project management}

The EHS Group was entitled as the Project manager, by which decisions on main characteristics of the CCCA design were made. Because of the urgent need of mass patients transfers, issued specifications documents were reduced to a strict minimal. Administrative ambulance regulations waiving was granted by the Prefecture des Hauts-de-Seine authority. Having the CCCA ready to operate took no more than 2 days.

The Project engineering included: risk assessment, adaptation of ambulance standards to a bus, compliance of medical \& technical procedures, quality assurance and ethical considerations. Special attention was given to easiness for entry, exit, as well as movements in the aisle, safeguarding from contamination and training.

\section{Conception}

\section{Equipment and design}

The CCCA equipment included: stretchers, portable medical and monitoring equipment, oxygen and power supply, all securely fastened. Design works focussed on the optimization of the interior space and separation of "contaminated" versus "clean" areas.
Two distinct areas were separated by a vertical vinyl film: a large "contaminated" area at the rear, and a smaller "clean" area at the front including the driver's compartment and a rest area. In the rear area, 6 groups of 4 seats each were removed, allowing for 6 stationary stretchers of the Snøgg ${ }^{\text {tw }}$ type to be rigged by retaining straps (Figs. 1 and 2). Air conditioning flow could not be completely shut down, and was reduced to the minimal.

The on-board equipment and healthcare personnel are listed in Table 1.

\section{Training of healthcare personnel}

Healthcare personnel operating the CCCA were all SAMU regular employees, working on a daily basis in ALS ambulances. Three of them were referent Chemical, Biological, Radiological and Nuclear (CBRN) instructors and all underwent regular training with personal protective equipment (PPE).

The driver was a volunteer employee of the Bus Company, with no additional training.

\section{Patient triage}

The exclusion rules were provided by the regional $S A M U$ zonal authority: patients with $\mathrm{FiO} 2>0.6$, or Norepinephrine $>0.2 \mathrm{mg} / \mathrm{h}$, or PEEP $>15 \mathrm{~cm} \mathrm{H} 2 \mathrm{O}$ were excluded.

\section{Assessment}

The CCCA prototype first testing was made by a dedicated healthcare team already assigned among regular SAMU healthcare workers.

Main evaluation criteria were: time to finalize bus preparation, time data (loading, unloading, transportation), adverse unexpected events, patients and personnel safety.

HCW's opinion on transfer conditions was collected in face to face interviews within the following days.

\section{Ethical consideration}

All the transfers were made with the informed consent of the patients' families. This survey obtained the MR003 approval required by the National Council for Statistical Information (CNIL).

\section{Results - trial run description}

On April 102,020, 4 COVID-19 patients from a hospital in the city of Corbeil (south of Île-de-France region) had to be transported to a Paris downtown station (Gare d'Austerlitz) prior to a transfer by a "hospital train" to Bordeaux (Nouvelle-Aquitaine region).

\section{Preparation}

The day before, members of the EHS Group have been completing the preparation of the bus in $1 \mathrm{~h} 30 \mathrm{~min}$. 

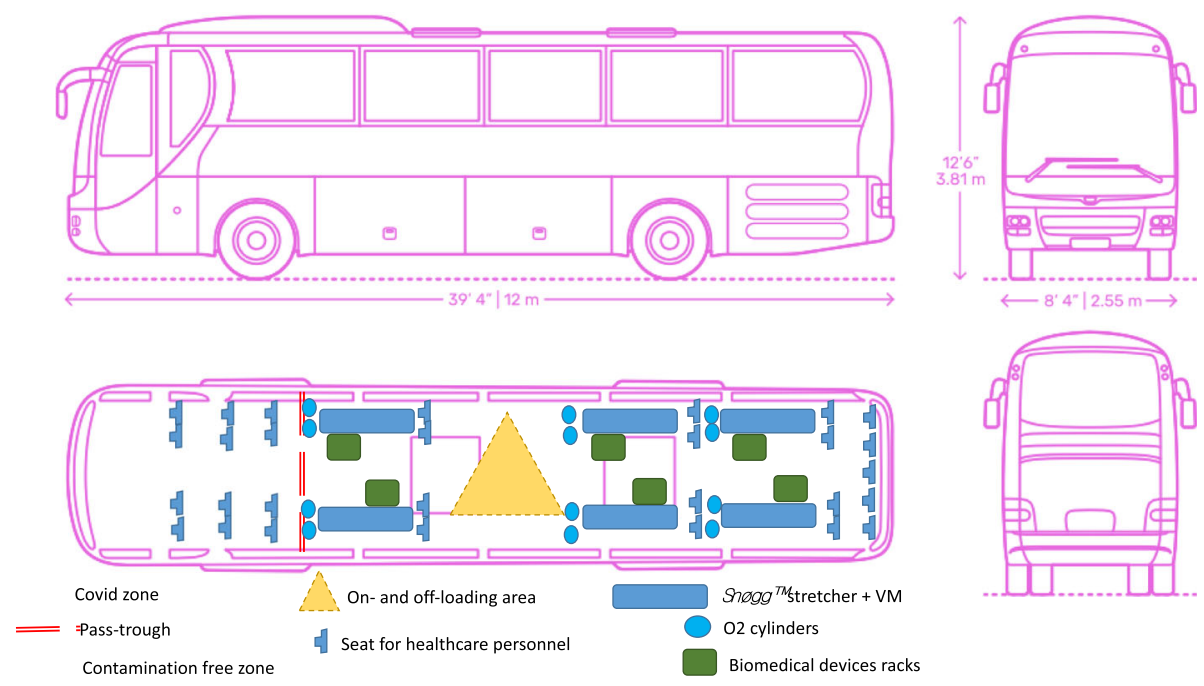

Fig. 1 Sides view of CCCA and functional layout showing more available workspace compared with classical ambulance

On D-day morning, CCCA went to Corbeil hospital and the healthcare team retrieved patients from ICUs at 6:05 am after getting dressed with PPE.

\section{Patients}

The four patients, 2 female and 2 male, 58 years old average, were in a stable condition. They all suffered from COVID-19 related Acute Respiratory Distress Syndrome (ARDS), and had been hospitalised for 15 days in average at Corbeil hospital. They all were under continuous sedation and curarisation, intubated and mechanically ventilated with volume cycled assist-control mode. One of them was receiving $0.2 \mathrm{mg} / \mathrm{h}$ of Norepinephrine. They were monitored with Invasive Blood Pressure, EtCO2, SpO2 and ECG.

\section{Time}

Patients' loading and unloading were different from routine operations with ALS ambulances.. Mean measured loading time was $1 \mathrm{~min} 39 \mathrm{~s}$. Mean measured unloading time was $1 \mathrm{~min} 15 \mathrm{~s}$. Loading and unloading are considered from right outside the bus door to installation in the workstation and inversely.

The CCCA departed Corbeil at 7:32 am and arrived at Gare d'Austerlitz station at 8:01 am. after a $37 \mathrm{~km}$ drive.

\section{Transportation}

Ventilation parameters and vasopressor agent infusion rate remained unchanged. Neither hemodynamic instability nor ventilation disorder has been observed. No harmful incident has occurred. Mutual support between

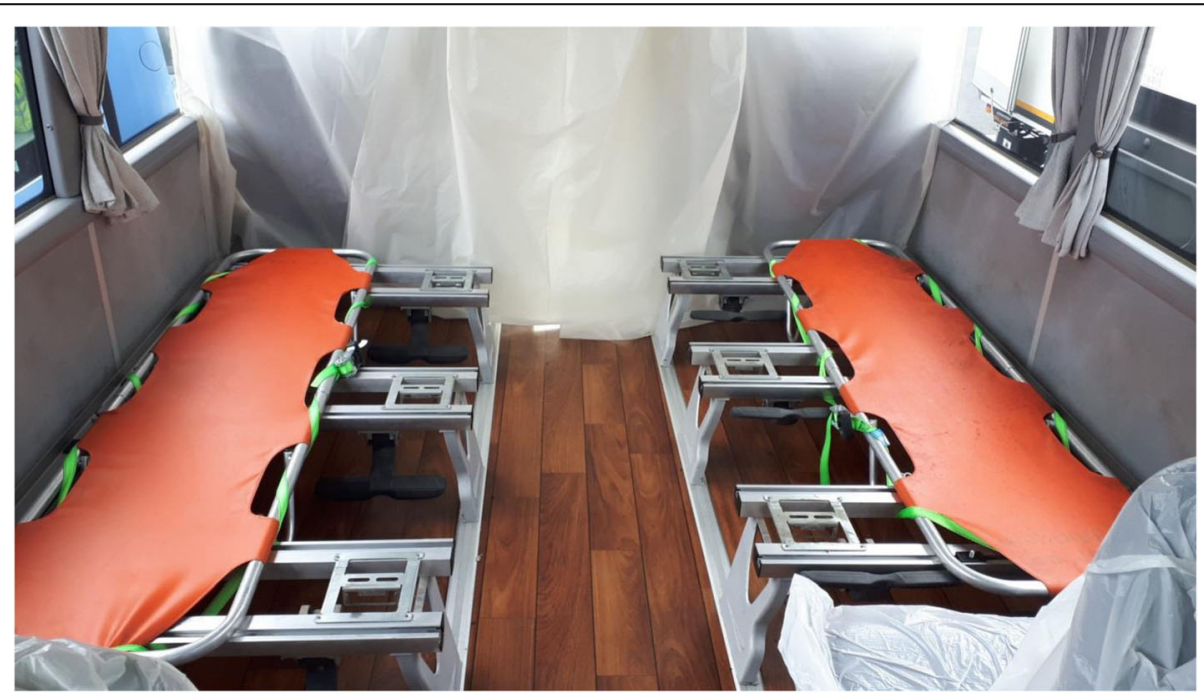

Fig. 2 Two workstations in the "contaminated" area at the rear of the CCCA. The vertical vinyl film (seen in the back) creates a separation from a "clean" area located at the front of the bus, including the driver's compartment and a rest area 
Table 1 Medical equipment \& personnel dedicated to CCCA transport

\begin{tabular}{|c|c|}
\hline Equipment & Count \\
\hline \multicolumn{2}{|l|}{ Medical equipment for each workstation } \\
\hline $\begin{array}{l}\text { Physio-Control Lifepak } 15^{\mathrm{TM}} \text { or Lifepak } 12^{\mathrm{TM}} \\
\text { multi-parametric monitor/defibrillator }\end{array}$ & $\begin{array}{l}1 \text { per } \\
\text { workstation }\end{array}$ \\
\hline Monnal $\mathrm{T}_{6} 0^{\mathrm{TM}}$ or Elisée $350^{\mathrm{TM}}$ ventilator & $\begin{array}{l}1 \text { per } \\
\text { workstation }\end{array}$ \\
\hline Syringe pumps & $\begin{array}{l}4 \text { per } \\
\text { workstation }\end{array}$ \\
\hline Suction unit & $\begin{array}{l}1 \text { per } \\
\text { workstation }\end{array}$ \\
\hline Vacuum Mattress (VM) & $\begin{array}{l}1 \text { per } \\
\text { workstation }\end{array}$ \\
\hline $3 \mathrm{~m}^{3}$ Oxygen Cylinders ( $p=200$ bars) & $\begin{array}{l}2 \text { per } \\
\text { workstation }\end{array}$ \\
\hline $\begin{array}{l}\text { Power supply by transformer and batteries } \\
\text { for Class II biomedical devices } \\
\text { (stand-alone time }=60 \mathrm{~h} \text { ) }\end{array}$ & $\begin{array}{l}1 \text { per } \\
\text { workstation }\end{array}$ \\
\hline Isothermal blanket & $\begin{array}{l}1 \text { per } \\
\text { workstation }\end{array}$ \\
\hline \multicolumn{2}{|l|}{ Additional pooled resources available for the 6 workstations } \\
\hline $\begin{array}{l}\text { Large container for intensive care consumables and } \\
\text { drugs }\end{array}$ & 1 \\
\hline $\begin{array}{l}\text { Large container for Personnel Protective Equipment } \\
\text { (PPE) including: } \\
\text { Disposable Tyvek Classic Plus }{ }^{\mathrm{TM}} \text { coveralls; } \\
\text { FFP2 Masks; } \\
\text { Gloves, shoe covers, etc. }\end{array}$ & 1 \\
\hline Abbott i-STAT System ${ }^{\text {TM }}$ blood analyser & 1 \\
\hline Hemocue $^{\mathrm{TM}}$ Hb 201 System for hemoglobin testing & 1 \\
\hline \multicolumn{2}{|l|}{ Spare equipment* } \\
\hline Spare ventilator & 1 \\
\hline $1 \mathrm{~m}^{3}$ Oxygen Cylinders ( $\mathrm{p}=200$ bars) & 6 \\
\hline ALS ambulance stretcher trolleys & 2 \\
\hline \multicolumn{2}{|l|}{ Healthcare personnel (CCCA medical team) } \\
\hline Doctors (senior - resident) & $2(1-1)$ \\
\hline Critical Care Nurses & 4 \\
\hline
\end{tabular}

*Spare equipment was boarded in the trunks (baggage compartments)

healthcare personnel was perceived as a distinct advantage, when compared to lonely teams in a single ALS ambulance each.

Two technical problems occurred during the retrieval phase:

- A touchscreen of a ventilator appeared to be frozen, implying a switch to the spare ventilator and a maintenance manoeuvre;

- An ECG monitoring cable proved defective and a spare one had to be brought from the base hospital.

In addition, the CCCA team reported that the entrance of the bus was a narrow pass through a little staircase. Loading and unloading a patient "packaged" in a VM (handled from the sides) was not easy.

\section{Discussion}

This experience was led in very good condition for patients, with no adverse effect during transport. It provided valuable information regarding collective evacuation by bus.

\section{Safety of transport}

As stated above, some minor equipment dysfunctions were experienced, hinting at the need of additional spare peripheral items (connectors ...) of every sensitive device.

There is no existing literature related to COVID-19 patients interhospital transportation so far. A 2016 review noticed that safety issues of interhospital transports were only recently the focus of some research [2]. Moreover, Droogh et al. [3] signalling that literature was addressing more often medical problems than technical ones, inventoried 55 types of such problems. Authors insisted as well on the ability of the transport team to resolve critical events, the rate of which was measured as concerning $16 \%$ of all patients in a 298 cases study [4], but a less worrisome $6.4 \%$ in another study involving 368 transports [5]. A 2020 evaluation of short-term mortality after 42,188 interhospital transports [6] advocates for transportation by ALS ambulance to minimize risks, as well as another study [7].

In summary, apart from having ample redundant spare items, the safety of such an interhospital transport relies essentially on the experience of assigned personnel. Specialized retrieval teams comprised of Emergency Medical Services (EMS) regular professionals (and not personnel whose work is restricted to the ICU) must be in charge, because of their specific knowledge of transport technical issues. The CCCA trial run personnel complied with this recommendation.

\section{Patients triage}

When the aim of an interhospital transfer is to debottleneck a healthcare system, risks must be reduced as much as possible.

Strauch et al. evaluated short-term outcomes and mortality after interhospital transports by using the Sequential Organ Failure Assessment (SOFA) score [5]. An Experts' Opinion [8] also recommended the SOFA score for pre-transport evaluation of patients, preferentially to the Simplified Acute Physiology Score (SAPS II) or the Acute Physiology and Chronic Health Evaluation Score (APACHE II). In this publication, patients were excluded if they met one of the following criteria: $\mathrm{PaO} 2 / \mathrm{FiO} 2$ ratio $<100$ with PEEP $>15 \mathrm{cmH} 2 \mathrm{O}$, or mean arterial pressure $<60 \mathrm{mmHg}$ despite adequate fluid therapy and vasoactive medication, or after cardiopulmonary resuscitation within $24 \mathrm{~h}$ prior to transport. 
In the CCCA trial run, the SAMU zonal did provide the exclusion rules: patients with $\mathrm{FiO} 2>0.6$, or Norepinephrine $>0.2 \mathrm{mg} / \mathrm{h}$, or PEEP $>15 \mathrm{~cm} \mathrm{H} 2 \mathrm{O}$ were excluded.

\section{Stretcher technique}

Commonly, patients transported in ALS ambulance are "packaged" in a Vacuum Mattress (VM). Undoubtedly useful for immobilization of trauma patients [9], the VM is not so convenient when moving patients through a narrow corridor because it needs to be handled from the sides.

The entrance of a bus is such a narrow pass. To facilitate access on board, the VM could be associated with a Scoop Stretcher, the former being anchored on the latter. This way, the whole "package" could be handled from both extremities, making the operation smoother.

Consequently, a Scoop Stretcher must be added to the CCCA equipment.

\section{Handover of patients}

SAMU of Hauts-de-Seine achieves annually 2200 interhospital transports. Its experience leads to emphasize the importance of a stage which interestingly was not stressed upon by the reviewed publications: the moment when devices connected to the patient in its ICU of origin, or in a given vector, have to be changed for other ones because of a handover. This coincides with the patient being moved from bed-to-stretcher (or stretcherto-stretcher, or stretcher-to-bed) and generally also with a change of the healthcare team in charge.

The trial run showed that a considerable lapse of time was spent for this procedure, compared to the loading and unloading times.

\section{Equipment changes}

During these bed/stretcher change movements, accidental extubation or catheter disinsertion are likely incidents.

Other sensitive operations during handover of patients are:

- Ventilator change with parameters potentially differing from one model to another;

- Invasive blood pressure to be reinitialised (for zerolevel);

- Syringe pumps to be changed with the risk of infusion irregularities;

- And a more or less brutal relocation of the patient onto a new surface.

Thus, limiting these equipment changes in interhospital transports is a safety matter, advocating for door-todoor capability of the vector.

\section{Crew changes}

When the responsibility of a critically ill patient is being transferred from a healthcare team to another, a comprehensive data transmission is mandatory [10]. A 2019 qualitative study of interhospital transports pointed out the discrepancy between the time spent on the road and the total time of the mission, explaining this by how time-consuming it was to prepare for a transport, collect information, etc. [11]

Again, limiting these crew changes in interhospital transfers pleads for door-to-door capability of the vector.

\section{Door-to door capability}

In their very comprehensive synthesis about methods and issues of interhospital individual transports of patients with ARDS, Jahn et al. [12] outlined the need for not losing time, particularly because of the inability to escalate the therapeutic while en route. They notably insisted on the two necessary intermediate legs of a transport by fixed-wings aircraft, i.e.: from airport to hospital and from hospital to airport, by comparison with helicopters which may land at the hospital itself.

Considering collective transportation vectors, fixedwings aircrafts and trains require these two intermediate legs between airport or station and hospitals, implying 4 crew changes/equipment changes.

For short distances, because of its door-to-door capability, a bus could be a suitable alternative to reduce these crew changes/equipment changes from 4 to 2 . The CCCA accommodating only up to 6 patients, a balanced study between vectors capacities and transport length has to be made on a case-by-case basis.

\section{Safeguarding from contamination}

Lockhart et al. [13] highlighted the risks associated with COVID-19 PPE doffing process, when healthcare workers "let their guard down".

During the "hospital train" trip subsequent to the first leg transport by CCCA, CBRN referent instructors set up a decontamination/doffing pass-through at the bottom of the staircase to the upper deck of the wagon (considered as a "safe area"), the "contaminated area" being by definition the lower deck. This allowed healthcare workers to have a rest during an extended period of work under PPE. This pass-through has to be added to the CCCA configuration for future long-distance transports.

Finally, the air-conditioning system $(\mathrm{A} / \mathrm{C})$ was set at the lowest pace because it could not be shut down, the quality of $\mathrm{A} / \mathrm{C}$ filters being unknown. Healthcare workers being under PPE, this was likely inconsequential for a short trip. For long-distance transports or patients under non-invasive ventilation (NIV), completely shutting down $\mathrm{A} / \mathrm{C}$ or considering high efficiency filters will be necessary. 


\section{Military vs civilian concept for collective evacuations} The French Army's Health Service has been developing since 2006 a collective strategic air medical evacuation capability known as Morphée (Module de Réanimation Pour Haute Élongation d'Évacuation) [14]. Aboard an Airbus A330 MRTT Phénix, it may accommodate 6 to 12 patients over a $10,000 \mathrm{~km}$ range.

There is a doctrinal difference between these military collective evacuation resources and the CCCA civilian solution: whereas the civilian vectors are a one-off and engineered for a specific situation, the military have been developing a medical support concept based on early strategic aeromedical evacuation (MEDEVAC) [15]. This strategic MEDEVAC itself is the third leg of a survival chain from the point of injury to homeland [16]. Obviously, these military evacuations have to be performed for patients whose clinical status is not in a stable condition and en route stabilization capabilities are mandatory [17], offering a distinct survival advantage [18].

Civilian-organised collective evacuations cannot address the wartime tactical or strategic situations, hence must be devoted to stabilized (triaged) patients, even if under critical care support, patients eligibility through an appropriate application of risk scores [8] must be evaluated.

During civilian disasters, it is conceivable that stabilized patients may be evacuated by a collective civilianorganised transport such as a CCCA, from the scene to remote hospitals. Another conceivable circumstance is a sudden important need of a sparse specific capability such as burn intensive care beds.

\section{Conclusion}

This first test of interhospital transport by a CCCA along a short distance with 4 patients was conducted in very good conditions, with no adverse effect or harmful incident. The experience brought a lot of information regarding safety, capabilities and time efficiency.

Compared to ALS ambulance accommodating a one only patient, the CCCA reduced the resources requirements by a lower personnel headcount, with more space, and improved indoor comfort conditions for staff. A foreseen prospect was a door-to-door capability minimalizing patients' handovers for safety concerns and time efficiency. The very short time allowed to organize, rule and conceptualize the CCCA characterizes the emergency context during this COVID-19 pandemic.

The next step would be to test the CCCA on a longdistance transport, in order to evaluate cost-benefit aspects and total transport delays reduction.

\section{Abbreviations}

A/C: Air-Conditioning System; ALS: Advanced Life Support; APACHE II: Acute Physiology and Chronic Health Evaluation Score; ARDS: Acute Respiratory Distress Syndrome; CCCA: Collective Critical Care Ambulance;
CBRN: Chemical, Biological, Radiological and Nuclear; CNIL: National Council for Statistical Information; COVID19: Corona Virus Disease 2019; ECG: Electrocardiogram; EHS: Exceptional Healthcare Situations; EMS: Emergency Medical Services; Etco2: End-Tidal Carbon Dioxide; Fi02: Fraction of Inspired Oxygen; HCW: Healthcare Workers; ICU: Intensive Care Unit; MEDEVAC: Aeromedical Evacuation; Morphée: Module de Réanimation pour Haute Élongation d'Évacuation: Collective Strategic Air Medical Evacuation Capability developed by the French Army; MR003: Méthodologie de Référence 003; NIV: Non-invasive ventilation; Pao2: Partial Pressure of Oxygen in Arterial Blood; PEEP: Positive End Expiratory Pressure; PPE: Personnel Protective Equipment; SAMU: Service d'Aide Médicale Urgente; SAPS II: Simplified Acute Physiology Score; SOFA: Sequential Organ Failure Assessment; Spo2: Saturation of Hemoglobin with Oxygen; VM: Vacuum Mattress

\section{Acknowledgements}

Authors thank Pr. Pierre Carli (SAMU de Paris) for his suggestion and for reviewing the manuscript. The authors are deeply grateful to Mathieu Duhamel (Directeur de cabinet du Préfet des Hauts-de-Seine) for his valuable assistance in drawing up this project and for connecting us with Transdev. Authors thank Alexis Fridman (Chef du Service Interministériel de Défense et de Protection Civile 92) for his support. Authors thank Transdev "the mobility company", especially Olivier Jilet (Directeur de l'établissement Transdev Montesson), Philippe Fenart (Directeur de flotte) and Philippe Gougeaud (CCCA driver) for their cooperation.

\section{Authors' contributions}

Substantial contributions to the conception and design of the work: TLE, CG, $C G, T L O$. Data analysis for the work: TLE, AC, AO, MB, TLO. Drafting the work: $T L E, C G, A O, M B, T L O$. Revising it critically for important intellectual content: TLE, CG, MB, TLO. Final approval of the version to be published: all authors.

\section{Funding}

No funding.

Availability of data and materials

All data generated or analysed during this study are included in this published article.

\section{Declarations}

Ethics approval and consent to participate

Data and analyses were done anonymously. This research was declared to the National Council for Statistical Information (CNIL), and our treatment is in accordance with MR No. 3. All the transfers were made with the informed consent of the patients' families.

Consent for publication

Not applicable.

\section{Competing interests}

The authors declare that they have no competing interests.

Received: 20 November 2020 Accepted: 27 May 2021

Published online: 04 June 2021

\section{References}

1. Marx J. Chardon's exercice. J Eur des Urgences et de Reanim. 2020;32(1):456. https://doi.org/10.1016/j.jeurea.2020.02.004.

2. Valentin A, Schwebel C. Into the out: safety issues in interhospital transport of the critically ill. Crit Care Med. 2016;42:1267-9.

3. Droogh JM, Smit M, Hut J, de Vos R, Ligtenberg JJ, Zijlstra JG. Inter-hospital transport of critically ill patients; expect surprises. Crit Care. 2012;16(1):R26. https://doi.org/10.1186/cc11191.

4. van Lieshout EJ, Binnekade J, Reussien E, Dongelmans D, Juffermans NP, de Haan RJ, et al. Nurses versus physician-led interhospital critical care transport: a randomized non-inferiority trial. Intensive Care Med. 2016;42(7): 1146-54. https://doi.org/10.1007/s00134-016-4355-y.

5. Strauch U, Bergmans DC, Winkens B, Roekaerts PM. Short-term outcomes and mortality after interhospital intensive care transportation: an observational prospective cohort study of 368 consecutive transports with a 
mobile intensive care unit. BMJ Open. 2015;5(4):e006801. https://doi.org/1 0.1136/bmjopen-2014-006801.

6. Kim TH, Song KJ, Shin SD, Ro YS, Hong KJ, Park JH. Effect of specialized critical care transport unit on short-term mortality of critically ILL patients undergoing Interhospital transport. Prehosp Emerg Care. 2020;24(1):46-54. https://doi.org/10.1080/10903127.2019.1607959.

7. Wiegersma JS, Droogh JM, Zijlstra JG, Fokkema J, Ligtenberg JJ. Quality of interhospital transport of the critically ill: impact of a Mobile intensive care unit with a specialized retrieval team. Crit Care. 2011;15(1):R75. https://doi. org/10.1186/cc10064.

8. Kiss T, Bölke A, Spieth PM. Interhospital transfer of critically ill patients. Minerva Anestesiol. 2017;83(10):1101-8. https://doi.org/10.23736/S0375-93 93.17.11857-2.

9. Prasarn ML, Hyldmo PK, Zdziarski LA, Loewy E, Dubose D, Horodyski M, et al. Comparison of the vacuum mattress versus the spine board alone for immobilization of the cervical spine injured patient: a biomechanical cadaveric study. Spine. 2017;42(24):E1398-402. https://doi.org/10.1097/BRS. 0000000000002260 .

10. Troyer L, Brady W. Barriers to effective EMS to emergency department information transfer at patient handover: a systematic review. Am J Emerg Med. 2020;38(7):1494-503. https://doi.org/10.1016/j.ajem.2020.04.036.

11. Eiding $\mathrm{H}$, Kongsgaard U, Braarud A. Interhospital transport of critically ill patients: experiences and challenges, a qualitative study. Scand J Trauma Resusc Emerg Med. 2019;27(1):27. https://doi.org/10.1186/s13049-019-0604-8.

12. Jahn N, Voelker MT, Bercker S, Kaisers U, Laudi S. Interhospitaltransport von Patienten mit ARDS [Interhospital transport of patients with ARDS]. Anaesthesist. 2017;66(8):604-13. https://doi.org/10.1007/s00101-017-0296-2.

13. Lockhart SL, Duggan LV, Wax RS, Saad S, Grocott HP. Personal protective equipment (PPE) for both anesthesiologists and other airway managers: principles and practice during the COVID-19 pandemic. Can J Anaesth. 2020;23:1-11.

14. Borne M, Tourtier JP, Ramsang S, Grasser L, Pats B. Collective air medical evacuation: the French tool. Air Med J. 2012;31(3):124-8. https://doi.org/10.1 016/j.amj.2011.09.002.

15. Luft A, Corcostegui SP, Millet M, Gillard J, Boissier J, Rondy P, et al. Aeromedical evacuations within the French armed forces: analysis of 2,129 patients. Mil Med. 2020;185(3-4):468-76. https://doi.org/10.1093/milmed/ usz268.

16. Boutonnet M, Raynaud L, Pasquier P, Vitiello L, Coste S, Ausset S. Critical care skill triad for tactical evacuations. Air Med J. 2018;37(6):362-6. https:// doi.org/10.1016/j.amj.2018.07.028.

17. Maddry JK, Ball EM, Cox DB, Flarity KM, Bebarta VS. En route resuscitation utilization of CCATT to transport and stabilize critically injured and unstable casualties. Mil Med. 2019;184(5-6):e172-6. https://doi.org/10.1093/milmed/ usy371.

18. Olson CM Jr, Bailey J, Mabry R, Rush S, Morrison JJ, Kuncir EJ. Forward aeromedical evacuation: a brief history, lessons learned from the global war on terror, and the way forward for US policy. J Trauma Acute Care Surg. 2013;75(2):S130-6. https://doi.org/10.1097/TA.0b013e318299d189.

\section{Publisher's Note}

Springer Nature remains neutral with regard to jurisdictional claims in published maps and institutional affiliations.

Ready to submit your research? Choose BMC and benefit from:

- fast, convenient online submission

- thorough peer review by experienced researchers in your field

- rapid publication on acceptance

- support for research data, including large and complex data types

- gold Open Access which fosters wider collaboration and increased citations

- maximum visibility for your research: over $100 \mathrm{M}$ website views per year

At $\mathrm{BMC}$, research is always in progress.

Learn more biomedcentral.com/submissions 